Varga, Zsuzsanna. "Selected English-Language Bibliography of Interest for Hungarian Cultural Studies: 2015-

2016." Hungarian Cultural Studies. e-Journal of the American Hungarian Educators Association, Volume 9 (2016):

http://ahea.pitt.edu DOI: 10.5195/ahea.2016.246

\title{
Selected English-Language Bibliography of Interest for Hungarian Cultural Studies: 2015-2016
}

\section{Zsuzsanna Varga}

\begin{abstract}
As the above title indicates, because of the publication schedule of Hungarian Cultural Studies this bibliography straddles 2015-2016, covering the period since the publication in Fall of 2015 of last year's bibliography in this journal. Each year's bibliography may also be supplemented by earlier items, which were retrieved only recently. Although this bibliography series can only concentrate on English-language items, occasional items of particular interest in other languages may be included. For a more extensive bibliography of Hungarian Studies from about 2000 to 2010, for which this is a continuing update, see Louise O. Vasvári, Steven Tötösy de Zepetnek, and Carlo Salzani. "Bibliography for Work in Hungarian Studies as Comparative Central European Studies." CLCWeb: Comparative Literature and Culture (Library) (2011): http://docs.lib.purdue.edu/clcweblibrary/hungarianstudiesbibliography.
\end{abstract}

Biography: Zsuzsanna Varga studied English, Hungarian and Portuguese language and literature at Eötvös Loránd University, Budapest. She received her PhD in nineteenth-century English literature at Edinburgh University. She has taught and researched at different British universities, including the University of Essex, UCL and De Montfort University. She has taught Hungarian Studies at Glasgow University since 2008, and she is also in charge of the Hungarian library collection at the University of Oxford. Her research interests include nineteenth-century women's writing, travel writing and translation history.

Acsády, Judit. 2011. "Diverse Constructions: Feminist And Conservative Women's Movements And Their Contribution To The (Re-)Construction Of Gender Relations In Hungary After The First World War." Aftermaths of War: Women's Movements and Female Activists, 1918-1923. Eds. Ingrid Sharpe and Matthew Stibbe. Leiden: Brill: 307-332.

Admiraal, Beth. 2015. "Religion and National Identity in Borderlands: Greek Catholics and Hungarian Reformed in Transylvania." Occasional Papers on Religion in Eastern Europe, 35.3: 17-42.

Almási, Gábor et al. 2014. A Divided Hungary in Europe: Exchanges, Networks and Representations, 1541-1699, 3 vols. Newcastle: Cambridge Scholars Publishing.

Almási, Gábor 2016. "Faking the National Spirit: Spurious Historical Documents in the Service of the Hungarian National Movement in the Early Nineteenth Century." Hungarian Historical Review 5.2: [n.p.]

Almási, Gábor and Lav Šubarić, eds. 2015. Latin at the Crossroads of Identity: The Evolution of Linguistic Nationalism in the Kingdom of Hungary. Leiden: Brill. 
Varga, Zsuzsanna. "Selected English-Language Bibliography of Interest for Hungarian Cultural Studies: 2015-

2016." Hungarian Cultural Studies. e-Journal of the American Hungarian Educators Association, Volume 9 (2016): http://ahea.pitt.edu DOI: 10.5195/ahea.2016.246

Andits, Petra. 2015. "Rethinking Home, Belonging and the Potentials of Transnationalism: Australian Hungarians After the Fall of the Berlin Wall.” Ethos 43.4: 313-331.

Armour, Ian D. 2014. Apple of Discord: The Hungarian Factor in Austro-Serbian Relations, 1867-1881. West Lafayette: Purdue University P.

Bacskai-Atkari, Julia. 2016. "The Hungarian Verse Novel in a Cross-Cultural Perspective." Worlds of Hungarian Writing. Eds. András Kiséry, Zsolt Komáromy and Zsuzsanna Varga. Madison: Fairleigh Dickinson UP: 93-106.

Bálint, Emese. 2015. "Migration and Survival of the Hutterite Brethren in Central Europe." Acta Ethnographica Hungarica 60.2: 267-285.

Bárány, András. 2015. "Inverse Agreement and Hungarian Verb Paradigms." Approaches to Hungarian, Volume 14: Papers from the 2013 Piliscsaba Conference. Eds. Katalin É. Kiss, Balázs Surányi and Éva Dékány. Amsterdam: Benjamins: 37-64.

Baumann, Viola. 2015. "Paradigm Acquisition and Conjugational Patterns in Hungarian Child Language." Within Language, Beyond Theories II: Studies in Applied Linguistics." Eds. Anna Bloch-Rozmej and Karolina Drabikowska. Newcastle Upon Tyne: Cambridge Scholars Publishing: 157-176.

Benczés, Réka and Erzsébet Tóth-Czifra. 2015. "Language Play and Linguistic Hybridity as Current Trends in Hungarian Word-Formation." Hungarian Cultural Studies 8: 1-11. http://dx.doi.org/10.5195/ahea.2015.212

Bergin, Tara. 2016. "Translating the Passion of Ravensbrück: Ted Hughes and János Pilinszky." Translating Holocaust Literature. Ed. Peter Arnds. Göttingen: Vandenhoeck \& Ruprecht: 23-31.

Bertha, Csilla and Donald E Morse. 2015. "Godot Comes to Hungary via Translation and Acculturation.” Litteraria Pragensia: Studies in Literature and Culture 25.50 : 75-91

Bohus, Kata. 2015. "Not a Jewish Question? The Holocaust in Hungary in the Press and Propaganda of the Kádár Regime during the Trial of Adolf Eichmann." Hungarian Historical Review 4.3: 732-772.

Bollók, Ádám. 2016. "Excavating Early Medieval Material Culture and Writing History in Late Nineteenth- and Early Twentieth-Century Hungarian Archaeology.” Hungarian Historical Review 5.2: [n.p.].

Borbély, Anna. 2016. "Sustainable Bilingualism and Language Shift: Longitudinal Research in Romanian-Hungarian Bilingual Kétegyháza (Hungary).” Acta linguistica Hungarica 63: 1: 2361.

Borgos, Anna. 2015. "Secret Years: 'Hungarian Lesbian Herstory, 1950s-2000s.”Aspasia 9:87112. 
Varga, Zsuzsanna. "Selected English-Language Bibliography of Interest for Hungarian Cultural Studies: 20152016." Hungarian Cultural Studies. e-Journal of the American Hungarian Educators Association, Volume 9 (2016): http://ahea.pitt.edu DOI: 10.5195/ahea.2016.246

Buchholz, Paul. 2015. "Eco-Romanticism: Terézia Moras Der einzige Mann auf dem Kontinent and the Re-Reading of Marlen Haushofer's Die Wand." Gegenwartsliteratur: A German Studies Yearbook 14 : 147-169.

Chmurski, Mateusz. 2015. "Review Article: The Wedding Gown Writes Back. Borgos, Anna. 2013. Nemek között: Nőtörténet, szexualitástörténet ('Between the Sexes: Women's History, Sexuality History'). Budapest: Noran Libro Kiadó. 317 pp.; and Lovas, Ildikó. 2008. Spanyol menyasszony ('The Spanish Bride'). Bratislava/Pozsony: Kalligram Kiadó. 304 pp. Hungarian Cultural Studies 8: 97-104. http://dx.doi.org/10.5195/ahea.2015.210

Cieger, András. 2015. "National Identity and Constitutional Patriotism in the Context of Modern Hungarian History: An Overview." Hungarian Historical Review 4.4: [n.p.].

Clemens, Ruthner, Diana Reynolds Cordileone, Ursula Reber and Raymond Detrez, eds. 2015. Wechselwirkungen: Austria-Hungary, Bosnia-Herzegovina, and the Western Balkans 1878-1918. New York: Peter Lang.

Czirfusz, Márton. 2015. "Making the Space-Economy of Socialist Hungary: The Significance of the Division of Labor." Hungarian Cultural Studies 8: 105-123. http://dx.doi.org/10.5195/ahea.2015.221 105-123

Czigány, Magda. 2009. "Just Like Other Students" Reception of the 1956 Hungarian Refugee Students in Britain. Newcastle: Cambridge Scholars Publishing.

Czigányik, Zsolt. 2015. "From the Bright Future of the Nation to the Dark Future of Mankind: Jókai and Karinthy in Hungarian Utopian Tradition." Hungarian Cultural Studies 8: 1223.http://dx.doi.org/10.5195/ahea.2015.213

Dékány, Éva and Veronika Hegedűs. 2015. "Word Order Variation in Hungarian PPs." Approaches to Hungarian, Volume 14: Papers from the 2013 Piliscsaba Conference. eds. Katalin É. Kiss, Balázs Surányi and Éva Dékány. Amsterdam: Benjamins: 95-120.

Demény, Tamás. 2016.“ Recontextualization, Localization, Hybridization: Intercultural Matrices in Hungarian Roma and African American Life Writings." Worlds of Hungarian Writing. Eds. András Kiséry, Zsolt Komáromy and Zsuzsanna Varga. Madison: Fairleigh Dickinson UP: 157-177.

Dikken, Marcel den. 2015. "The Morphosyntax of (In)Alienably Possessed Noun Phrases- The Hungarian Contribution. "Approaches to Hungarian, Volume 14: Papers from the 2013 Piliscsaba Conference. Eds. Katalin É Kiss, Balázs Surányi, and Éva Dékány. Amsterdam: Benjamins: 121-145.

Eötvös, József. 2015. Poverty in Ireland. 1837. A Hungarian's View. Szegénység Irlandban. Trans. Paul Sohar and Lászlo Bakos. Dublin: Phaeton.

Erdélyi, Gabriella. 2015. "Confessional Identity and Models of Aristocratic Conversion in Seventeenth- and Eighteenth-Century Hungary.” Social History 40.4: 473-496. 
Varga, Zsuzsanna. "Selected English-Language Bibliography of Interest for Hungarian Cultural Studies: 2015-

2016." Hungarian Cultural Studies. e-Journal of the American Hungarian Educators Association, Volume 9 (2016): http://ahea.pitt.edu DOI: 10.5195/ahea.2016.246

Fazekas, Csaba. 2015. “Genesis of 'Hungarism': Bishop Ottokar Prohaszka and the Extremist Right in 1920s Hungary." Occasional Papers on Religion in Eastern Europe 35.5: 41-66.

Fehérváry, Krisztina. 2013. Politics in Color and Concrete: Socialist Materialities and the Middle Class in Hungary. Bloomington: Indiana University Press.

Feichtinger, Johannes and Gary B. Cohen, eds. 2014. Understanding Multiculturalism: The Habsburg Central European Experience. New York: Berghahn.

Fejérdy, András. 2015. Pressed by a Double Loyalty: Hungarian Attendance at the Second Vatican Council, 1959-1965, Budapest: CEU UP.

Fodor, Mónika. 2015. “'We Just Are:' Narrative Construction of Liminality in Bidirectional Assimilation among Second- and Third-Generation Hungarian-Americans." Contested Identities: Literary Negotiations in Time and Place. Eds. Roger Nicholson, Claudia Marquis and Gertrud Szamosi. Newcastle Upon Tyne: Cambridge Scholars: 235-254.

Foteva, Ana. 2014. Do the Balkans Begin in Vienna? The Geopolitical and Imaginary Borders between the Balkans and Europe. New York: Peter Lang.

Gagyi, Agnes and Mark Aron Eber. 2015. "Class and Social Structure in Hungarian Sociology." East European Politics and Societies and Cultures 29.3: 598-609.

Gal, Susan. 2015. "Imperial Linguistics and Polyglot Nationalisms in Austria-Hungary: Hunfalvy, Gumplowicz and Schuchard.” Balkanistica 28.1:151-173.

Győri, Róbert. 2015. “Communist Geography Instead of Nationalist Geography: The New Cadres and the Case of Sándor Radó.” Hungarian Cultural Studies 8: 124-146. http://dx.doi.org/10.5195/ahea.2015.222

Haglund, David G. and Umut Korkut. 2015. “Going Against the Flow: Sinn Fein's Unusual Hungarian 'Roots” International History Review 37.1: 41-58.

Halm, Tamás. 2015. "Free Choice and Aspect in Hungarian." Approaches to Hungarian, Volume 14: Papers from the 2013 Piliscsaba Conference. Eds. Katalin É Kiss, Balázs Surányi and Éva Dékány. Amsterdam: Benjamins: 167-185.

Heins, Laura. 2016. “The 'Psyche of the White Man' and the Mass Face on Film: Béla Balázs between Racialist and Marxist Physiognomics." New German Critique 127: 59-89.

Hites, Sándor. 2016. "Mediation and Hybridity: Twentieth-Century Hungarian Émigré Literary Scholars." Worlds of Hungarian Writing. Eds. András Kiséry, Zsolt Komáromy and Zsuzsanna Varga. Madison: Fairleigh Dickinson UP: 123-142.

Hörcher, Ferenc. 2016. "Enlightened Reform or National Reform? The Continuity Debate about the Hungarian Reform Era and the Example of the Two Széchenyis (1790-1848)." Hungarian Historical Review 5.1: [n.p.]. 
Varga, Zsuzsanna. "Selected English-Language Bibliography of Interest for Hungarian Cultural Studies: 20152016." Hungarian Cultural Studies. e-Journal of the American Hungarian Educators Association, Volume 9 (2016): http://ahea.pitt.edu DOI: 10.5195/ahea.2016.246

Horváth, Györgyi. 2016. "The Cultural (Un)Turn in Hungarian Literary Scholarship in the 1990s: Strategies of Inclusion and Exclusion.” Worlds of Hungarian Writing. Eds. András Kiséry, Zsolt Komáromy and Zsuzsanna Varga. Madison: Fairleigh Dickinson UP: 179-198.

Hudácskó, Brigitta. 2016 "And Then There Were Many: Agatha Christie in Hungarian Translation." The Ageless Agatha Christie: Essays on the Mysteries and the Legacy. Ed. J. C. Bernthal. Jefferson: McFarland: 130-144.

Menyhért, Anna. Írónők a hálón. http://ironok.elte.hu/

Jobbitt, Steven. 2015. "Regime Change and the Attempted Rehabilitation of Self: Ferenc Fodor and the Production of Communist Geography, 1948-1962." Hungarian Cultural Studies 8: 147164. http://dx.doi.org/10.5195/ahea.2015.223

Judson, Pieter M. 2016. The Habsburg Empire: A New History. Cambridge: Harvard UP.

Kádár, Judit. 2015. "Two Austro-Hungarian Women Writers, Anna Tutsek and Terka Lux, Creating New Urban Identities in Early Twentieth-Century Budapest." Hungarian Cultural Studies 8: 24-33. http://dx.doi.org/10.5195/ahea.2015.214

Kallius, Annastiina. 2016. "Immobilizing Mobility: Border Ethnography, Illiberal Democracy, and the Politics of the 'Refugee Crisis' in Hungary." American Ethnologist 43.1: 25-37.

Kasza, Péter. 2015. "On the Track of an Edition: New Sources for the Dating of Stephanus Brodericus' Historia Verissima.” Colloquia Maruliana 24 : 193-206.

Kasznár, Attila. 2016. "The Chinese Culture and Hungary." Occasional Papers on Religion in Eastern Europe 36.3:15 -24

Kavoulakos, Konstantinos. 2015. "The Drama in an Age of Fragmentation: Toward a New Reading of Georg Lukács's Evolutionary History of the Modern Drama." New German Critique 124: 23-44.

Keményfi, Róbert. 2015. "The Mythical Power of the Dual River-System of the Carpathian Basin: The Notion of a Hungarian Mesopotamia." Hungarian Cultural Studies 8: 165186.http://dx.doi.org/10.5195/ahea.2015.219

Kérchy, Anna. 2015. "On the Hungarian Translations of Alice: 'The Last Reservatories of Lost Human Freedom." Alice in a World of Wonderlands: The Translations of Lewis Carroll's Masterpiece. Volume One: Essays. Eds. Jon A. Lindseth and AlanTannenbaum. New Castle: Oak Knoll--Lewis Carroll Society of North America: 294-298.

Kiefer, Ferenc. 2015. "The Privative Derivational Suffix in Hungarian: A New Account." Negation in Uralic Languages. Eds. Matti Miestamo, Anne Tamm and Beáta Wagner-Nagy. Amsterdam: Benjamins: 601-614. 
Varga, Zsuzsanna. "Selected English-Language Bibliography of Interest for Hungarian Cultural Studies: 2015-

2016." Hungarian Cultural Studies. e-Journal of the American Hungarian Educators Association, Volume 9 (2016): http://ahea.pitt.edu DOI: 10.5195/ahea.2016.246

Kiséry, András and Zsolt Komáromy. 2016. "Introduction: World Literature in Hungarian Literary Culture.” Worlds of Hungarian Writing. Eds. András Kiséry, Zsolt Komáromy and Zsuzsanna Varga. Madison: Fairleigh Dickinson UP: 1-27.

Kiséry, András, Zsolt Komáromy and Zsuzsanna Varga, eds. 2016. Worlds of Hungarian Writing. Madison: Fairleigh Dickinson UP.

Kiss, Katalin É. 2015. "Negation in Hungarian.” Negation in Uralic Languages. Eds. Matti Miestamo, Anne Tamm and Beáta Wagner-Nagy. Amsterdam: Benjamins: 219-237.

Komáromy, Zsolt. 2016. ““'Wordsworth in Hungary”: An Essay on Reception as Cultural

Memory and Forgetting.” Worlds of Hungarian Writing. Eds. András Kiséry, Zsolt Komáromy and Zsuzsanna Varga. Madison: Fairleigh Dickinson UP: 29-51.

Korzenszky, Tamás. "Traditional Hungarian Romani/Gypsy Dance and Romanian Electronic Pop-Folk Music in Transylvania." Acta Ethnographica Hungarica 60.1: 43-51.

Kovács, Tamás. 2015. "Detours in the Life of a General: Ferenc Kisbarnaki Farkas, Order of Vitéz.” Journal of Slavic Military Studies 28.1: 239 -258.

Küchler, Ulrike. 2015. "Alien Art: Encounters with Otherworldly Places and Inter-Medial Spaces." Alien Imaginations: Science Fiction and Tales of Transnationalism. Eds. Ulrike Küchler and Gillian Beer. London: Bloomsbury: 31-55.

Kurdi, Mária. 2015. "Ireland and the Irish on the Hungarian Stage: Recent Productions of the Plays from Synge to Friel and Beyond." Litteraria Pragensia: Studies in Literature and Culture 25.50: 60-74.

Laczó, Ferenc. 2016. Hungarian Jews in the Age of Genocide Leiden: Brill.

Louthan, Howard and Graeme Murdock, eds. 2015. A Companion to the Reformation in Central Europe, Leiden: Brill.

Lóránd, Zsófia. 2015. "Exhibiting Rape, Silencing Women: Alaine Polcz in the House of Terror in Budapest." East Central Europe 42.2-3: 321-342.

MacDonald, Ágnes Vashegyi. 2016. “Antal Szerb's The Queen's Necklace: A “True Story” of Cross-Cultural Intersections in Hungarian Literature" Worlds of Hungarian Writing. Eds. András Kiséry, Zsolt Komáromy and Zsuzsanna Varga. Madison: Fairleigh Dickinson UP: 107-121.

Magyar, Bálint. 2016. Post-Communist Mafia State: The Case of Hungary. Budapest: CEU UP.

Magyar, Bálint and Júlia Vásárhelyi. 2016. Twenty-Four sides of a Post-Communist Mafia State. Budapest: CEU UP. 
Varga, Zsuzsanna. "Selected English-Language Bibliography of Interest for Hungarian Cultural Studies: 2015-

2016." Hungarian Cultural Studies. e-Journal of the American Hungarian Educators Association, Volume 9 (2016): http://ahea.pitt.edu DOI: 10.5195/ahea.2016.246

Majtényi, Balázs and György Majtényi. 2015. A Contemporary History of Exclusion: the Roma Issue in Hungary from 1945 to 2015. Budapest: CEU UP.

Maxwell, Alexander. 2016. "Hungaro-German Dual Nationality: Germans, Slavs, and Magyars during the 1848 Revolution." German Studies Review 39.1: 17-39.

Mazsu, János. 2015. "Jewish Settlement in Prohibited Cities: Jewish Immigration into Debrecen in the period 1790-1870." East Central Europe 42.2-3: 181-216.

Michels, Georg B. 2015. "Myth or Reality? Ottoman Support for Hungarian Rebels in Light of a Secret Transylvanian Mission to the Porta (1669-1670)." Hungarian Cultural Studies 8: 34-45. http://dx.doi.org/10.5195/ahea.2015.220

Mulcahy, Richard P. with János Angi and Tibor Glant, eds. 2012. Hungary through the Centuries: Studies in Honor of Steven Bela Vardy and Agnes Huszar Vardy. Boulder: East European Monographs.

Nagy, Balázs, Martyn Rady, Katalin Szende and András Vadas, eds. 2016. Medieval Buda in Context. Leiden: Brill.

Nemes, Robert. 2016. Another Hungary: The Nineteenth-Century Provinces in Eight Lives. Standford UP.

Némethy, Kesserü Judith, ed. 2015. Twenty-First Century Hungarian Language Survival in Transylvania. Saint Helena: Helena History Press.

Nicholson, Roger, Claudia Marquis and Gertrud Szamosi. 2015. Contested Identities: Literary Negotiations in Time and Place. Newcastle: Cambridge Scholars Publishing.

Orbán, Katalin. 2016. "Monuments and Bulldozers: Social Memory Landscapes in Péter Esterházy's Celestial Harmonies and Donald Barthelme's The Dead Father." Worlds of Hungarian Writing. Eds. András Kiséry, Zsolt Komáromy and Zsuzsanna Varga. Madison: Fairleigh Dickinson UP: 243-259.

Paltineanu, Oana Sinziana. 2015. "Converging Suffrage Politics: 'The Romanian Women's Movement in Hungary and Its Allies before World War I."Aspasia 9: 44 -64.

Pethö, Ágnes 2015. The Cinema of Sensations. Newcastle: Cambridge Scholars Publishing.

Péteri, György. 2016. "Contested Socialisms: the Conflict between Critical Sociology and Reform Economics in Communist Hungary, 1967-71." Social History 41.3: 249-266.

Pető, Andrea. 2015. "Hungary 1956: Júlia Rajk or the Power of Mourning" Clio. Women. Gender. History, 41.1: 153-164.

Poggi, Isotta. 2015. "The Photographic Memory and Impact of the Hungarian 1956 Uprising during the Cold War Era." Getty Research Journal, 7: 197-206 
Varga, Zsuzsanna. "Selected English-Language Bibliography of Interest for Hungarian Cultural Studies: 2015-

2016." Hungarian Cultural Studies. e-Journal of the American Hungarian Educators Association, Volume 9 (2016): http://ahea.pitt.edu DOI: 10.5195/ahea.2016.246

Pope-Fischer, Lisa. 2016. Symbolic Traces of Communist Legacy in Post-Socialist Hungary. Leiden: Brill.

Randolph L. Braham and András Kovács, eds. 2016. The Holocaust in Hungary: Seventy Years Later. Budapest: CEU UP.

Rady, Martyn. 2016. "Nonnisi in sensu legum? Decree and Rendelet in Hungary (1790-1914)." Hungarian Historical Review 5.1: [n.p.].

Rákosi, György and Enikő Tóth. 2016. "The Pronoun Interpretation Problem in Child Hungarian.” Acta Linguistica Hungarica. 63.1: 659-674.

Rieber, Alfred J. 2014. The Struggle for the Eurasian Borderlands: From the Rise of Early Modern Empires to the End of the First World War. Cambridge: Cambridge UP.

Romsics, Ignác. 2016. "War in Puszta: The Great War and the Hungarian Peasantry." The Great War and Memory in Central and South-Eastern Europe. Ed. Oto Luthar. Leiden: Brill: 38-54.

Rosen, Ilana. 2015. "The Poetry of 1.5 and Second-Generation Israelis of Hungarian Origin." Hungarian Cultural Studies 8: 46-62. http://dx.doi.org/10.5195/ahea.2015.218

Ruttkay, Veronika. 2016. "Negotiating the Popular/National Voice: Impropriety in Two Hungarian Translations of Robert Burns." Worlds of Hungarian Writing. Eds. András Kiséry, Zsolt Komáromy and Zsuzsanna Varga. Madison: Fairleigh Dickinson UP: 53-74.

Sălăgean, Tudor. 2016. Transylvania in the Second Half of the Thirteenth Century. Leiden: Brill.

Séllei, Nóra. 2015. "Katherine Mansfield's Early Translations and Reception in Hungary." Katherine Mansfield and Continental Europe: Connections and Influences, Eds. Janka Kascakova and Gerri Kimber. London: Palgrave Macmillan: 26-39.

Selyem, Zsuzsa. 2015. "How Long and When: Open Time Interval and Dignified Living Creatures in The Turin Horse." Acta Universitatis Sapientiae: Film and Media Studies 10.1 : 105-120.

Scholten, Jeep. 2016. Comrade Baron. A Journey through the Vanishing World of the Transylvanian Aristocracy. Saint Helena: Helena History Press.

Schwartz, Agatha. 2015. "Éva Heyman, the Hungarian Anne Frank: Writing Against Persecution and Trauma." Hungarian Studies Review 42.1-2 : 117-134.

Silverman, Lisa. 2015. "Leopoldstadt, Judenplatz, and Beyond: Rethinking Vienna's Jewish Spaces.” East Central Europe, 42.2-3: 249-267.

Subaric, Lav. 2015. "National Identities and the Latin Language in Hungary and Croatia: Language Conflicts, 1784-1848." Major Versus Minor? Languages and Literatures in a Globalized World. Eds. Theo D'haen, Iannis Goerlandt and Roger D. Sell. Amsterdam: Benjamins: 53-66. 
Varga, Zsuzsanna. "Selected English-Language Bibliography of Interest for Hungarian Cultural Studies: 20152016." Hungarian Cultural Studies. e-Journal of the American Hungarian Educators Association, Volume 9 (2016): http://ahea.pitt.edu DOI: 10.5195/ahea.2016.246

Szakács, Béla Zsolt. 2016. The Visual World of the Hungarian Angevin Legendary. Budapest: CEU UP.

Szántó, Ildikó. 2015. "Hungarian Population Discourses in the Twentieth Century: The Problem of Declining Birth Rates.” Hungarian Cultural Studies 8: 63-78.

http://dx.doi.org/10.5195/ahea.2015.215

Szatek-Tudor, Karoline. 2015. "The Power of Storytelling: Bird Tales by Shakespeare and Hungarians." Contested Identities: Literary Negotiations in Time and Place. Eds. Roger Nicholson, Claudia Marquis and Gertrud Szamosi. Newcastle: Cambridge Scholars Publishing: 67-86.

Széchényi, Kinga. 2015. Stigmatized: A History of Hungary’s Internal Deportations during the Communist Dictatorship. Saint Helena: Helena History Press.

Szegedy-Maszák, Mihály. 2016. "The Hungarian Reception of George Eliot." The Reception of George Eliot in Europe. Eds. Elinor Shaffer and Catherine Brown. London: Bloomsbury Academic: 336-347.

Szívós, Erika. 2015. "Historic Jewish Spaces in Central and Eastern European Cities.” East Central Europe. 42.3: 139-162.

Szívós, Erika. 2011. Social History of Fine Arts in Hungary, 1867-1918. East European Monographs. Boulder: Social Science Monographs.

Takács, Ádám. 2015. "Marxism in Revolution: Georg Lukács's History and Class Consciousness and Karl Korsch's Marxism and Philosophy." 1922: Literature, Culture, Politics Ed. Jean-Michel Rabaté. Cambridge: Cambridge UP: 219-234.

Taylor, Jeffrey. 2014. In Search of the Budapest Secession: The Artist Proletariat and Modernism's Rise in the Hungarian Art Market, 1800-1914. Saint Helena: Helena History Press.

Török, Borbála Zsuzsanna. 2015. Exploring Transylvania: Geographies of Knowledge and Entangled Histories in a Multiethnic Province, 1790-1918. Leiden: Brill.

Túry, György. 2016. “The New Left's Use and Abuse of György Lukács's Thought.” Worlds of Hungarian Writing. Eds. András Kiséry, Zsolt Komáromy and Zsuzsanna Varga. Madison: Fairleigh Dickinson UP: 143-156.

Sutt, Cameron. 2015. Slavery in Árpád-Era Hungary in a Comparative Context. Leiden: Brill.

Til, Jon Van and Péter Krasztev, eds. 2015. The Hungarian Patient: Social Opposition to an Illiberal Democracy. Budapest: CEU UP.

Toth, Helena. 2014. An Exiled Generation: German and Hungarian Refugees of Revolution, 1848-1871. Cambridge: Cambridge UP. 
Varga, Zsuzsanna. "Selected English-Language Bibliography of Interest for Hungarian Cultural Studies: 2015-

2016." Hungarian Cultural Studies. e-Journal of the American Hungarian Educators Association, Volume 9 (2016): http://ahea.pitt.edu DOI: 10.5195/ahea.2016.246

Tóth, Zsuzsa. 2010. Foreign Language Anxiety and the Advanced Language Learner: A Study of Hungarian Students of English as a Foreign Language. Newcastle: Cambridge Scholars Publishing.

Vincze, Hanna Orsolya. 2012. The Politics of Translation and Transmission: Basilikon Doron in Hungarian Political Thought. Newcastle: Cambridge Scholars Publishing.

Varga, Zoltán. 2015.’Look Behind the (Animated) Pictures. Notes on the Role of the Aesopic Language in Hungarian Animated Film. Acta Universitatis Sapientiae: Film and Media Studies 10.1: 121-139.

Varga, Zsuzsanna. 2016. "Translation, Modernization, and the Female Pen: Hungarian Women as Literary Mediators in the Nineteenth Century." Worlds of Hungarian Writing. Eds. András Kiséry, Zsolt Komáromy and Zsuzsanna Varga. Madison: Fairleigh Dickinson UP: 75-92.

Varga, Zsuzsanna. 2013. “A Transylvanian Lady Traveller: Polyxéna Wesselényi’s Travels in Italy and Switzerland."Transnational Identities of Women Writers in the Austro-Hungarian Empire. New York: Addleton Academic Publishers: 179-196.

Vasvári, Louise O. 2015. "En-gendering Memory through Holocaust Alimentary Life Writing." CLCWeb: Comparative Literature and Culture 17.3

http://docs.lib.purdue.edu/clcweb/vol17/iss3/10/

Venkovits, Balázs. 2010. "Writing with Devotion, Drawing with Light: Images of the Americas in Nineteenth Century Hungarian Travelogues." Metamorphoses of Travel Writing. Eds. Grzegorz Moroz and Jolanta Sztachelska. Newcastle: Cambridge Scholars Publishing: 104-113.

Walsh, Lauren. 2016. "Text, Image, Memory: Intermediality in the Work of Péter Nádas" Worlds of Hungarian Writing. Eds. András Kiséry, Zsolt Komáromy and Zsuzsanna Varga. Madison: Fairleigh Dickinson UP: 219-242.

Waters, Leslie M. 2015. "Adjudicating Loyalty: Identity Politics and Civil Administration in the Hungarian-Slovak Borderlands, 1938-1940." Contemporary European History 24.3: 351 -374.

Watson, Alexander. 2014. Ring of Steel: Germany and Austria-Hungary in World War I. New York: Basic Books.

Winick, Amber. 2015. "Lessons from Objects: Designing a Modern Hungarian Childhood 18901950.” Hungarian Cultural Studies 8: 79-96.http://dx.doi.org/10.5195/ahea.2015.216

Wolf, Michaela. 2015. The Habsburg Monarchy's Many-Languaged Soul: Translating and Interpreting, 1848-1918. Amsterdam: Benjamins.

Zimonyi, István. 2016. Muslim Sources on the Magyars in the Second Half of the Ninth Century. Leiden: Brill. 
Varga, Zsuzsanna. "Selected English-Language Bibliography of Interest for Hungarian Cultural Studies: 2015-

2016." Hungarian Cultural Studies. e-Journal of the American Hungarian Educators Association, Volume 9 (2016): http://ahea.pitt.edu DOI: 10.5195/ahea.2016.246

Zupka, Dušan. 2016. Ritual and Symbolic Communication in Medieval Hungary under the Árpád Dynasty (1000 - 1301), Leiden: Brill.

Zsadányi, Edit. 2016. "Borderline Fiction: Eastern Europe and East-West Encounters in László Krasznahorkai’s Works. "Worlds of Hungarian Writing. Eds. András Kiséry, Zsolt Komáromy and Zsuzsanna Varga. Madison: Fairleigh Dickinson UP: 199-218. 